\title{
Determination of Competition Conventional Bank in Banking Industry in
} Indonesia

\author{
Ciplis Gema Qori'ah",*, Mochammad Ridwan G. ${ }^{\mathrm{a}}$, Adhitya Wardhono ${ }^{\mathrm{a}}$, Ika Nurjannah ${ }^{\mathrm{a}}$ \\ ${ }^{a}$ Department of Economics and Development Studies - Faculty of Economics and Business - Universitas Jember
}

\begin{abstract}
The aim of this study is to determine the level of concentration and competition behavior of conventional commercial banks in the national banking industry. This study focuses on descriptive analysis and quantitative analysis using panel data regression for 9 conventional commercial banks during 2003-2014. Results of eclectic analysis are supposed that behavior of banks is less competitive due to high levels of concentration in the banking industry. While the results of panel data regression show that the variables of bank interest expense, operating expense, other operating incomes and variable of loanable funds significantly affect the income of conventional banks.
\end{abstract}

Keywords: Bank Competition; Panel Data Regression; Banking Industry

\begin{abstract}
Abstrak
Tujuan dari penelitian ini adalah untuk mengetahui tingkat konsentrasi dan perilaku persaingan bank umum konvensional yang terdapat di industri perbankan nasional. Penelitian ini memfokuskan pada analisis deskriptif dan analisis kuantitatif dengan menggunakan regresi data panel dengan sampel 9 bank umum konvensional selama 2003-2014. Hasil analisis menunjukkan bahwa perilaku bank kurang kompetitif karena tingkat konsentrasi yang tinggi di industri perbankan. Sedangkan hasil menunjukkan regresi data panel bahwa variabel beban bunga bank, beban operasional, pendapatan operasional lainnya, dan dana pinjaman signifikan berpengaruh pada pendapatan bank konvensional.
\end{abstract}

Kata kunci: Kompetisi Bank; Regresi Data Panel; Industri Perbankan

JEL classifications: B21; C23; L80

\section{Introduction}

Banks have a major role on the financial of a country. Bank is not only as an intermediary institution funds from the community but also as instrument to facilitate payment system and monetary stability in the economy (VanHoose 2010; Mishkin 2008). The banking industry dominating financial sector in Indonesia is less than 80 percent of the financial sector total asset, while the rest is dominated by the financial industry such as insurance, security, the fund pension, and pawning (Bank Indonesia 2010; Andriawan 2012). Banking industry is an industry in which intensive capital has a very high risk. This

* Corresponding Address: Jalan Kalimantan 37 Kampus Bumi Tegal Boto, Universitas Jember, Jember 68121. E-mail: ciplisqoriah@gmail.com. situation is responded by Bank Indonesia (BI) to make a policy to reduce the growth rate of business of banking industry through the banking restructure (Mulyaningsih \& Daly 2011; Gajurel \& Pradhan 2012). One of the policy is Indonesian Banking Architecture (API) which is basic framework of a comprehensive Indonesia banking system in relatively long term.

The target of API policy becomes a driving factor for restructuring and competitive national banking. (Yildrim \& Philippatos 2006; Mulyaningsih \& Daly 2011). In one of the pillars of API policy,it enforces Good Corporate Governance (GCG) to strengthen internal condition of national banking system, so banks are required to increase its scale to meet minimum number of criteria which must be fulfilled by the bank. All the banks which could 
not meet the minimum capital requirements can be consolidated in the form of a merger or acquisition (Bikker \& Groenevald 2000; Demirgüç-Kunt, Laeven, \& Levine 2004; Yildrim \& Phillipatos 2006). Consolidation is one of the effective policies to increasing banking competitive and all the inefficient banks get out from banking industry (VanHoose 2010). Consolidation policy aims at strengthening bank capital adequacy and maintaining the bank endurance to face risk.

The consolidation has an impact on market structure of national banking and leads to improve concentration and competition in national banking industry. Competition in the banking sector, especially financial institutions becomes interesting topics. This is in accordance with the management of financial institutions that varies with the advancement of information technology and increasing challenges by banks. The development of information technologies led to fast progressively development of kind and complexity of the products and services the bank so that the risks appear to be greater and varied. Bank competition is an instrument of the bank which may occur through competitive deposit and credit. This is because each bank which competes to apply strategies influencing the decision on the other banks (VanHoose 2010). If a bank chooses a strategy to reduce the mortgage interest rate, it will be responded by other banks.

Several studies have tried to examine competition in Indonesian banks, including Claessen \& Laeven (2004) who estimated the level of competition in 50 countries including Indonesia using the PanzarRosse method over the period 1994-2001. From these studies it was noted that the Indonesian banking industry structure belonged to the category of monopolistic competition5. Results of this study were also supported by de Rozas (2007) which arrived at the same conclusion in Spain. Thus, the purpose of this study is to determine the level of concentration and competition behavior of commercial banks in the national banking Industries.

\section{Literature Review}

Mulyaningsih \& Daly (2011) examine high concentration and the competition among banks in Indonesia which shows that the bank working in market is competition monopolistic. Analysis of concentration in the market results shows that the market banks in Indonesia to are less concentrated. Overall the increase of distribution markets can reduce concentration market and increase competition. In line with Mulyaningsinh \& Daly (2011), Berger, Klapper, \& Turk (2008) took the sample of 8235 banks which operate in 23 different industrialized countries, they found evidence that there is consistency of the traditional related fragility competition banks with high market forces. Research results of also show that market forces increase the credit risk.

Claessens \& Laeven (2004) said that banking competition in financial sector could encourage efficiency in production sector, product quality, finance and high innovation. Then Patti and Dell'ariccia (2004) explained that the increasing competition is also expected to be able to reduce costs intermediation becoming more efficient because it needed time to apply for credit and eventually it will have an effect to the bank. In reverse, Cetorelli (2001) said that higher interest rates will decrease investments, so that innovation will hamper and decrease company's productivity in the end.

Competition testing of financial institutions by Schaeck, Čihák, \& Wolfe (2006) analyzes rosscountry relationship between the measurement of competition financial institutions and the fragility banking system by observing 38 countries during the period 1980-2003. The figures showed that the more competitive banking system, the less susceptible systemic crisis is. Then Fungacova \& Weill (2009) consider that fragility bank's failure, from the perspective of a micro-finance, was found in Russia during the period of 2001-2007. They use index Lerner (IL) as a measure competition bank and analysis of logit panel to see the effects of competition in the failure bank. The results indicate that intense competition can damage financial stability.

\section{Method}

\subsection{Type and data source}

Type of data in this research is panel data with annual periods which started in 2003-2014, with cross section data of 9 banks for the conventional banks. This research takes 9 banks for each type of banks that has assets and significant credit. Data obtained 
Table 1: The Sample list of Banks

\begin{tabular}{|c|c|c|}
\hline No & Chategory & Bank \\
\hline 1 & Bank & $\begin{array}{l}\text { Bank Mandiri (Persero), Tbk } \\
\text { Bank Rakyat Indonesia (Persero) Tbk } \\
\text {. Bank Negara Indonesia (Persero) Tbk }\end{array}$ \\
\hline 2 & Foreign exchange BUSN & $\begin{array}{l}\text { Bank Central Asia, Tbk } \\
\text {. Bank Danamon Indonesia, Tbk } \\
\text {. Bank CIMB Niaga, Tbk }\end{array}$ \\
\hline 3 & BPD & $\begin{array}{l}\text { BPD West Java and Banten, Tbk } \\
\text { BPD Bank of East Java } \\
\text { Bank DKI }\end{array}$ \\
\hline
\end{tabular}

from the annual report of Financial Services Authority (OJK) webpage. The sample list of banks in this study is shown in Table 1.

\subsection{Model specification}

Specification of the model used in this study is adapted from the research of Mulyaningsih \& Daly (2011). Thespecification of the model can be written as follows:

$$
\begin{aligned}
R E V_{\cdot i t}= & \beta_{0}+\beta_{1} I N T_{i t}+\beta_{2} O P S_{i t}+\beta_{3} R O P_{i t} \\
& +\beta_{4} E Q_{i t}+\beta_{5} L O_{i t}+\beta_{6} L F_{i t}+e_{i t}
\end{aligned}
$$

where:

$R E V_{\cdot i}$ : The ratio of interest income to total assets yearly;

$I N T_{i t}$ : The ratio of interest expense to total annual deposits;

$O P S_{i t}$ : The operational expensesratioof total assets yearly;

$R O P_{i t}$ : The ratio of other income ratioof the total annual asset;

$E Q \cdot i t$ : Equity divided by total assets;

$L O_{i t}$ : Loans divided by total assets;

$L F_{i t}$ : The Third-party fund divided by total assets; $E_{i t}:$ Error term.

\subsection{Data and Methods Analysis}

The methods used in analyzing banking competition are divided into two types, namely descriptive analysis methods and quantitative analysis methods. The purpose of using both methods in research is to support each other and to strengthen the results. In addition, by giving an object description or comprehension supported by counting quantitative analysis it can strengthen the previously descriptive analysis.

\subsection{Descriptive Analysis}

Descriptive analysis in this research is used to answer an empirical question about the concentration level and bank competition in Indonesia after the API policy. Eclectic analysis expected to describe the competition phenomenon in the national banking industry by using a recapitulation reflection and raw data to provide easier understanding. The high concentration and competition in national banking industry will be calculated by using Concentration Ratio (CR). Extension of vote counting results will be presented in the tables form, graphs and descriptive sentences (narratives).

\subsection{Quantitative Analysis}

Quantitative Analysis is used to answer questions about the empirical level of competition in national banking industry. The method of analysis used is quantitative methods regression data panel. Data is a joint panel from cross-section and time series, where data are collected from a cross section and followed a specific time period (Nachrowi 2006). Thus panel analysis of data has $T$ period of time ( $t$ $=1,2, \ldots, T)$ and $\mathrm{N}$ number of individual $(\mathrm{i}=1,2, \ldots$, $\mathrm{N}$ ) then the data on observation panel will be of NT.

The reason why uses methods of panel regression is because regression cross-section is not able to meet dynamics cross-time variables into the model. 
While the research aims at competition to observe national banking industry phenomenon during the time period, so that it needs panel to a regression analysis (Mulyaningsih \& Daly 2011; De Bandt \& Davis 2010). Panel data regression has several models, such as Pooled Least Square (PLS), Fixed Effect Model (FEM), and Random Effects Model (REM).

\subsection{Model Selection Method}

Determining model which will be used in this regression analysis of panel data is based on two testing, Hausman test and Chow test (Nachrowi 2006). Chow test is used to determine the most suitable model for Pooled Least Square (PLS) and Fixed Effect Model (FEM). Chow Testing is intended to provide an alternative choice of determining model in a way of multiple panel regression analysis. Meanwhile, Hausman testing is used to determine the most suitable model between Fixed Effect Model (FEM) and random Effect Model (REM). Chow and Hausman Testing can be conducted through some stages:

\subsubsection{Chow test}

Determining a model that will be used between pooled least Square (PLS) and Fixed Effect Model (multiple regression analysis $\mathrm{FEM}$ ) in data panel can be conducted through Chow testing as follows:

$$
\text { Trial Statistics: } F=\frac{(R R S S-U R S S) /(N-1)}{(U R S S) /(N T-N-")}
$$

where:

$R S S S$ : Sum Restricted Residual Squared from Pooled Least Square (PLS);

$U R S S$ : Sum Unrestricted Residual Squared from

Fixed Effect Model (FEM);

$N$ : Cross Section;

$Q$ : Time series;

$K$ : independent variables.

F statistic decision $>\mathrm{F}$ table $(\mathrm{N}-1, \mathrm{NT}-\mathrm{N}-\mathrm{K})$ model is the most suitable for regression analysis panel data of Fixed Effect Model (FEM). Hausman Testing is still necessary to determine which is the most suitable model used, whether Fixed Effect Model (FEM) or random Effect Model (REM).

\subsubsection{Hausman test}

Hausman test is used to determine which is the most suitable model between Fixed Effect Model (FEM) and random Effect Model (REM). Hausman test is conducted if the results of Chow test hypothesis of probability cross section random are $<\alpha$, so it can be concluded that the most appropriate model for multiple regression analysis panel data is Fixed Effect Model (FEM) than Effect Model (REM).

\section{Results and Analysis}

Performance competition in Indonesia Banking Industry Performance competition for banking industry in Indonesia will be analyzed through the approach analysis of market structure banks in Indonesia. Analysis of market structure will be done to know what kind of competition that applies to Indonesia banking industry, where it was obtained from the market share from several major banks or the one that is often known by counting Concentration Ratio (CR).

The ratio measurement concentration in this research is based on the market share assets, depositor funds, and credit. The measurement concentration ratio will be a determining factor in principle to the market share of assets, but it also analyzes the ratio or concentration based on the market share third-party fund and market share credit. This is intended to analyze more responsible market for the ratio concentration based on the market share assets. Table 2 shows that banking industry in Indonesia's market structure which is likely to shape an oligopoly market. It causes to control over the assets of more than 50 percent which still concentrate in five major banks; PT Bank Mandiri Tbk, PT Bank Central Asia Tbk, PT Bank Rakyat Indonesia Tbk, PT Bank Indonesia Indonesia Tbk, PT Bank Danamon Indonesia Tbk.

In 2003, structure market of Indonesia banking industry is oligopoly. This is because the market shared assets of 54.2 percent of the total market share assets economy can only be used by some large banks alone (CR-5). In 2004 to 2014 the segment of assets value has declined. This is because API policy in that year would also set up single current policy and regulation based on minimum 
Table 2: Market Share based on assets of the Indonesia Banking Industry

\begin{tabular}{lrrrrrr}
\hline \hline Tahun & Mandiri & BRI & BNI & BCA & Danamon & CR-5 Aset \\
\hline 2003 & $20.26 \%$ & $7.80 \%$ & $10.84 \%$ & $10.96 \%$ & $4.34 \%$ & $54.20 \%$ \\
2004 & $18.90 \%$ & $8.41 \%$ & $10.70 \%$ & $11.69 \%$ & $4.53 \%$ & $54.24 \%$ \\
2005 & $17.30 \%$ & $8.35 \%$ & $10.01 \%$ & $10.18 \%$ & $4.54 \%$ & $50.39 \%$ \\
2006 & $15.13 \%$ & $9.13 \%$ & $9.97 \%$ & $10.40 \%$ & $4.70 \%$ & $49.33 \%$ \\
2007 & $15.27 \%$ & $10.25 \%$ & $9.16 \%$ & $10.93 \%$ & $4.36 \%$ & $49.98 \%$ \\
2008 & $14.65 \%$ & $11.43 \%$ & $8.67 \%$ & $10.59 \%$ & $4.54 \%$ & $49.87 \%$ \\
2009 & $14.61 \%$ & $12.42 \%$ & $8.90 \%$ & $11.08 \%$ & $3.81 \%$ & $50.83 \%$ \\
2010 & $16.24 \%$ & $15.83 \%$ & $9.56 \%$ & $12.79 \%$ & $4.52 \%$ & $58.94 \%$ \\
2011 & $13.39 \%$ & $12.50 \%$ & $7.90 \%$ & $10.33 \%$ & $4.26 \%$ & $48.38 \%$ \\
2012 & $13.21 \%$ & $12.56 \%$ & $7.54 \%$ & $10.25 \%$ & $3.06 \%$ & $46.62 \%$ \\
2013 & $13.06 \%$ & $12.21 \%$ & $7.47 \%$ & $9.84 \%$ & $3.06 \%$ & $45.65 \%$ \\
2014 & $13.74 \%$ & $14.12 \%$ & $7.14 \%$ & $9.83 \%$ & $2.96 \%$ & $47.79 \%$ \\
\hline \hline
\end{tabular}

Source: Indonesian Statistics banks

Note: Bank rank based on the largest share

amount of paid bank. In 2009 and 2010 market structure backed to oligopoly tight with the value of each segment 50.83 percent in 2009 and 58.94 percent in 2010, but in 2014 the assets fell back to 47.79 percent to to loose oligopoly market structure.

Based on previous description it can be concluded that the change of market structure in Indonesia banking industry from tight oligopoly to light-binding oligopoly did not affect bank performance. Because the change of segment percentage is not so big every year, it is around $1 \%-8 \%$ per year. Imbalance proportion is owned by five big banks in Indonesian banking industry. Thus, more than 50 percent market share assets of the Indonesia banking industry can only be used by five banks, while the rest is controlled by more than 100 banks that belongs to the conventional public bank. Counting concentration ratio does not only focus on the market share assets but also the depositor funds. This is because depositor funds in banking activity are one of the indicators that influenced the development of assets and credit from a bank. Thus, the count concentration ratio is also carried out against the depositor funds by using data segment Third-party fund from five biggest banks (CR-5 Third-party fund).

Based on Table 3, it will be known that the overall results of CR- 5 show that the shape market structure of Indonesia banking industry is light-binding oligopoly. Because the market segment depositor funds which are less than 50.00 of the total share of Third-party fund, overall share is just dominated by a few large banks only (CR-5).

In 2003, the segment of Third-party fund is worth 49.46 percent, market share depositor funds are less than the $50 \%$, so at the end of 2003 , Indonesian banking market is close to oligopoly tight, starting in 2004 to 2008 the segment of Third-party fund decreased, but it does not transform market structure in Indonesia banking industry. In 2009 the segment depositor funds rise to 49.35 percent. Therefore, in 2010 by the end of 2013 the segment depositor funds are 48.16 and 48.07 percent below $50 \%$, thus market structure of Indonesia banking industry includes into the category of oligopoly loose.

Based on explanation above it can be concluded that the shape market structure of banking industry in Indonesia during 2008-2014 is consistent in the form oligopoly loose. This is because more than 50 percent market share During the banking industry in Indonesia can only be used by five banks, while the rest is controlled by more than 100 banks belonging to the group of conventional commercial bank

From the CR5 in Table 4 indicates that the shape market structure of Indonesia banking industry is light binding oligopoly. Because the market segment depositor funds which are less than 50.00 of the total share of economy assets can only be used by some large banks. In 2003 the segment was 49.16 percent credit high-value below 50 percent, so market structure of Indonesia banking industry is oligopoly loose, also in 2004-2014 when the market share credit for about $46 \%-50 \%$.

Based on previous explanation it can be concluded that banking industry in Indonesia is still concentrated on some large banks which are not equally distributed to cause oligopoly market, because most of the CR-5 is based on the market share assets and credit having concentration ratio below $50 \%$ 
Table 3: Market Share Based on Third-Party Fund in Indonesia Banking Industry

\begin{tabular}{rrrrrrr}
\hline \hline & Mandiri & BRI & BNI & BCA & Danamon & CR-5 \\
\hline 2003 & $19.82 \%$ & $8.58 \%$ & $11.71 \%$ & $4.87 \%$ & $4.47 \%$ & $49.46 \%$ \\
2004 & $17.65 \%$ & $8.56 \%$ & $10.83 \%$ & $5.81 \%$ & $4.17 \%$ & $47.01 \%$ \\
2005 & $17.65 \%$ & $8.60 \%$ & $10.16 \%$ & $6.39 \%$ & $3.93 \%$ & $46.73 \%$ \\
2006 & $15.34 \%$ & $9.67 \%$ & $10.49 \%$ & $6.35 \%$ & $4.21 \%$ & $46.06 \%$ \\
2007 & $15.61 \%$ & $10.95 \%$ & $9.57 \%$ & $6.99 \%$ & $3.80 \%$ & $46.92 \%$ \\
2008 & $15.60 \%$ & $11.49 \%$ & $9.14 \%$ & $7.97 \%$ & $4.22 \%$ & $48.42 \%$ \\
2009 & $15.36 \%$ & $13.03 \%$ & $9.46 \%$ & $8.05 \%$ & $3.44 \%$ & $49.35 \%$ \\
2010 & $14.23 \%$ & $14.05 \%$ & $8.10 \%$ & $8.39 \%$ & $3.40 \%$ & $48.16 \%$ \\
2011 & $13.65 \%$ & $13.36 \%$ & $8.07 \%$ & $9.02 \%$ & $3.19 \%$ & $47.30 \%$ \\
2012 & $13.50 \%$ & $13.52 \%$ & $7.72 \%$ & $9.87 \%$ & $2.81 \%$ & $47.42 \%$ \\
2013 & $13.64 \%$ & $13.27 \%$ & $7.66 \%$ & $10.52 \%$ & $2.97 \%$ & $48.07 \%$ \\
2014 & $14.21 \%$ & $14.81 \%$ & $7.37 \%$ & $10.73 \%$ & $2.84 \%$ & $49.96 \%$ \\
\hline
\end{tabular}

Source: Indonesian banks Statistics

Note: Ranked bank in sort based on the largest share

Table 4: Market Share based on Credit in Banking industry Indonesia

\begin{tabular}{rrrrrrr}
\hline \hline & Mandiri & BRI & BNI & BCA & Danamon & CR-5 \\
\hline 2003 & $16.64 \%$ & $10.79 \%$ & $10.56 \%$ & $6.66 \%$ & $4.52 \%$ & $49.16 \%$ \\
2004 & $15.83 \%$ & $11.15 \%$ & $10.22 \%$ & $7.22 \%$ & $5.17 \%$ & $49.59 \%$ \\
2005 & $14.42 \%$ & $10.86 \%$ & $8.89 \%$ & $7.79 \%$ & $5.14 \%$ & $47.10 \%$ \\
2006 & $13.81 \%$ & $11.40 \%$ & $8.27 \%$ & $7.77 \%$ & $5.16 \%$ & $46.40 \%$ \\
2007 & $12.66 \%$ & $11.36 \%$ & $8.67 \%$ & $8.24 \%$ & $5.08 \%$ & $46.01 \%$ \\
2008 & $12.16 \%$ & $12.32 \%$ & $8.33 \%$ & $8.63 \%$ & $4.91 \%$ & $46.34 \%$ \\
2009 & $12.50 \%$ & $14.30 \%$ & $8.18 \%$ & $8.62 \%$ & $4.16 \%$ & $47.75 \%$ \\
2010 & $12.40 \%$ & $13.99 \%$ & $7.52 \%$ & $8.72 \%$ & $4.25 \%$ & $46.88 \%$ \\
2011 & $12.45 \%$ & $12.89 \%$ & $7.19 \%$ & $9.19 \%$ & $4.16 \%$ & $45.89 \%$ \\
2012 & $12.56 \%$ & $12.86 \%$ & $7.13 \%$ & $9.48 \%$ & $3.38 \%$ & $45.40 \%$ \\
2013 & $12.66 \%$ & $13.08 \%$ & $7.27 \%$ & $9.49 \%$ & $3.16 \%$ & $45.65 \%$ \\
2014 & $13.21 \%$ & $13.64 \%$ & $7.30 \%$ & $9.65 \%$ & $2.98 \%$ & $46.77 \%$ \\
\hline \hline
\end{tabular}

Source: Statistics Indonesian banks

Note: Bank rank based on the largest share 
(CR-50 5\%), where this value shows high moderate concentration banks in Indonesia.

\subsection{Results of The Descriptive Statis- tic Analysis}

Descriptive Statistic Analysis will show the behavior of each independent variable in influencing the movement of the dependent variable. The dependent variable was a revenue variable (REV.) that uses interest income ratio of total assets from each bank examined, while the independent variables used are ratio of interest expense to total annual deposits (INT), ratio of operational expenses to total assets yearly (OPS), the ratio of other income ratio of the total annual asset (ROP), ratio Equity divided by total assets (EQ), Loans divided by total assets (LO), and The Third-party fund (LF). But descriptive statistics results from these variables that has been mentioned above can be seen in Table 5.

Table 5 shows the revenue variable of banks that have a competitiveness variation. This can be seen from maximum value based on interval and minimum each variable which is very far. Maximum value variable REV. have and the value of 0.163 minimums of 0.062 where there is a very long interval between with minimum score maximum. So, the variables have maximum value INT with a minimum score of 0.555 and 0.046 of a very long interval results that happened fluctuations in the income and interest expenses each bank. Like the REV and INT, the variable $\mathrm{EQ}$ also has a maximum and minimum interval that is very much where value EQ maximum of 0.188 and minimum score of 0.058 . This indicates that happened fluctuations in the variable EQ.

The variable LO also experienced fluctuation as other variables above. Fluctuation was reflected from the interval between the value maximum and minimum of 0.767 and 0.220 . Meanwhile, maximum value variable LF have minimum score of 0.852 and 0.325 , where these results show that range interval that is very much between maximum value with minimum score. Unlike the OPS that did not show that there were no fluctuations where interval between maximum value and the minimum not so far of 0,084 and 0,018 . More variables ROP has fluctuated as the variable OPS. Fluctuation was reflected through interval between a maximum and minimum that was not so much that is equal to 0.039 and 0,005 . The presentation conclusion that only the SOUP and ROP that do not experience fluctuations while the REV., INT, EQ, LO, and LF, high fluctuation mainly in response to the competition in Indonesian banks.

The estimation results presented above in addition to compare the fluctuations in the variable data used are also intended to provide an overview of the data distribution of each variable used in the study through the value of standard deviation and average value. Distribution of bank income variable data can be categorized into good data distribution. It will be known by comparison the standard deviation and value of average -price variables REV. that have the 0.022 and 0.099 where shows the standard deviation that was smaller than average value.

In line with variable REV, INT variable distribution meets the criteria of good data, where the standard deviation than average value of 0.088 and 0.161 . Like the variable INT, the variable OPS also meet the criteria encircle data is good, where the standard deviation than average value of 0.011 and 0.041 . Variable ROP also meet the criteria encircle data that is where the standard deviation of 0.007 value of average and 0.014 in the standard of a smaller deviation value of average compared with average.

Furthermore, the variable EQ have the criteria data is good, where the standard deviation of 0.026 and the average of 0.108 that shows the standard deviation that more small compared to average value. So encircle data in the variable LO that have the standard deviation of 0.124 and the average of 0.554 that indicate the standard deviation more small compared with average value, so as to meet the criteria encircle data is good. Encircle data, which is also shown by the LF where the standard deviation more small compared to the average of 0.094 and 0.740 . These are providing conclusion that overall distribution of variables had good data. This was reflected the standard deviation through of each variable which more small compared to average value. 
Table 5: The Mean, Median, Maximum, Minimum, and Standard deviation each variable

\begin{tabular}{lrrrrrrr}
\hline \hline & REV. & INT & OPS & ROP & EQ. & LO & LF \\
\hline Mean & 0.099 & 0.161 & 0.041 & 0.014 & 0.108 & 0.544 & 0.74 \\
Median & 0.098 & 0.138 & 0.039 & 0.013 & 0.102 & 0.572 & 0.77 \\
Max & 0.163 & 0.555 & 0.084 & 0.039 & 0.188 & 0.767 & 0.852 \\
Sun & 0.062 & 0.046 & 0.018 & 0.004 & 0.058 & 0.22 & 0.325 \\
Std. Dev. & 0.022 & 0.088 & 0.011 & 0.007 & 0.026 & 0.124 & 0.094 \\
Obs & 108 & 108 & 108 & 108 & 108 & 108 & 108 \\
\hline \hline \multicolumn{7}{l}{ Source: The Data sourced from Indonesian Banking Statistics - } \\
\multicolumn{7}{l}{ The Authority Financial Services }
\end{tabular}

\subsection{Result of the estimation methods Regression Analysis Data Panel}

Before estimated by using regression analysis data panel, need to be the election best models using Chow and Hausman test. Based on the analysis of causality relation which will be done by using regression analysis data panel, then the following result.

Table 6: Chow-Test

\begin{tabular}{lccc}
\hline \hline Effects Test & Statistics & D. f. & Prob. \\
\hline Cross-section F & 13.563304 & $(8.93)$ & 0.0000 \\
Cross-section Chi-square & 83.507955 & 8 & 0.0000 \\
\hline \hline Source: The Data sourced from Indonesian Banking \\
\multicolumn{4}{c}{ Statistics - The Authority Financial Services }
\end{tabular}

Testing Chow aims to find out which model more precise method used in regression data panel, where this test will compare between models Pooled Least Square or Fixed Effect a more precise used in Table 6 shows research. result of the estimation Chow test that has been done in analysis of bank competition. Result of the estimation in top shows that the values probability chi-square $(0.000)$ more small compared with probability critical $(\alpha=$ $5 \%=0.05)$. This indicates that model Fixed Effect is better than Pooled least Square (PLS).

Testing Hausman -test will be done if test result Chow showing a model Fixed Effect that better. Testing Hausman aims to find out which model more precise method used in regression data panel, where this test will compare between models Random Effect or Fixed Effect a more precise used in research. Table 7 will show result of the estimation Hausman-Test that has been done in analysis of bank competition.

The estimation results above shows a probability Chi-Squared (0.1247) higher than $\alpha(\alpha=5 \%=0.05)$ so based on Hausman testing it can be concluded that a model right multiple regression analysis is used in panel data in this research is a model Fixed Effect.

Analysis of bank competitions approached with panel data regression approach using variable income(REV) as the dependent variable is a proxy of bank competition, while independent variables that are used such as variable ratio of interest expense to total annual deposits (INT), ratio of operational expenses to total assets yearly (OPS), the ratio of other income ratio of the total annual asset (ROP), ratio Equity divided by total assets (EQ), Loans divided by total assets (LO), The Third-party fund (LF). The results of the estimation competition bank by using this method regression analysis data panel are shown by the Table 8 .

The estimation result showed that the variable INT, OPS, ROP, and LO significantly affected by the values $R E V$ with $t$-count greater than of t-table. In addition, with a probability $\mathrm{t}$-count of the four independent variables from $0.0000,0.0000,0.0037$ and 0.0014 on the value smaller compared to $\alpha$ $(\alpha=5 \%=0.0500)$. This explains that the bank's revenue(REV) is significantly affected by interest expense on total deposits (INT), operational expenses are proxied by the ratio of operating expenses to total assets(OPS), other revenues of each bank are proxied by the ratio of other income, others to total assets (ROP) and it is affected by the liquidity risk of each bank which are proxied by the ratio of loans

Table 7: HausmanTest

\begin{tabular}{lccc}
\hline \hline Test Summary & $\begin{array}{c}\text { Chi-Sq. } \\
\text { Statistics }\end{array}$ & $\begin{array}{c}\text { Chi-Sq. } \\
\text { d.f. }\end{array}$ & Prob. \\
\hline Cross-section random & 37.443558 & 6 & 0.0000 \\
\hline Source: The Data sourced from Indonesian Banking \\
Statistics - The Authority Financial Services
\end{tabular}


to total assets (LO).

Variable Advanced EQ and LF did not significantly affect the amount REV. with the t-count less than ttable. In addition, with a probability t-count from second independent variables from 0.6462 and 0.4998 that shows more value than $\alpha(\alpha=5 \%=0.05)$. Thus the variable $E Q$ and LF did not significantly affect the great REV.

However, if the test is done simultaneously, a whole sixth variables significantly affect the amount of revenue by each bank received (REV) that can be seen from $\mathrm{F}$-count that is greater than the F-table as well as the probability of the F-count with the 0.0000 on the value smaller compared to $\alpha(\alpha=5 \%=0.0500)$. In addition, the estimation results also showed that the adjusted $R^{2}$ as big as 0.8373 that explained that all independent variables affect as big as $83.73 \%$ affect the amount of income each bank, while the rest were influenced by other variables outside the model.

Overall, the banks conventional are in an oligopoly competition at the end of 2003 to 2014 . This condition is different from previous studies about competition banking in Indonesia, including Setyowati (2004) which concluded that that the situation Indonesian banks as a whole is monopolistic competition. In line with Setyowati, Chandler (1983) who explained that in the banking industry there is no perfect competition but there are only competition monopolies or oligopoly. But a competition in the banking industry in Indonesia has changed since its Indonesian Banking Architecture (API) launch in the form of monopolistic competition turning to the situation oligopoly. These conditions in competition public banks tend to become low and intense.

Table 8: Result of The Bank Estimation Competitions (Panel Data)

\begin{tabular}{lccc}
\hline \hline Variable & Coefficient & T-Statistic & Prob. \\
\hline C & 0.084209 & 6.144 .531 & 0.0000 \\
INT? & 0.107440 & 5.621 .187 & 0.0000 \\
OPS? & 0.866810 & 5.963 .482 & 0.0000 \\
ROP? & -0.767165 & -2.978 .255 & 0.0037 \\
EQ? & -0.033694 & -0.460521 & 0.6462 \\
LO? & -0.059895 & -3.300 .493 & 0.0014 \\
LF? & 0.013404 & 0.677504 & 0.4998 \\
\hline Adj R sqr & & 0.8373 & \\
F-count & 34,189 \\
Prob (F-Stat) & & 0.0000 \\
\hline \hline Source: The Data sourced from Indonesian Banking \\
\multicolumn{4}{c}{ Statistics - The Authority Financial Services }
\end{tabular}

Some of the factors that affects on conventional bank competition can be seen on the liabilities side. On the liabilities side, interest expenses, increased competition may encourage an increase third party fund interest because banks tend to promote a new customer enticement through interest rate that is higher than their competitors. In other operational expenses, one of the factors that determine the competition in the future considering the operational burden is cost of labor and other factors of production cost, so that it can be concluded that there is a direct relationship between operational expenses with the conventional bank. The volume of distribution loan or credit is also a determinant of competition in the banking sector. Since credit distribution will create the bank through interest rate, the margin is narrow than in the form the interbank money market (PUAB) and commercial paper. Credit distribution more banks will invite greater income and vice versa.

\section{Conclusion}

Based on the calculation of concentration ratio (CR5 ) it can be concluded that the level of concentration in the industry banking belong to the moderate concentration where there are some banks that dominate the market share exceeds $50 \%$ of the total share of the total market industry. High concentration causes national banking industry on the less competitive environment industry. That causes five biggest banks that were found behaving oligopoly. In addition, the result of analysis quantitative using methods regression analysis data panel, it can be concluded that almost half of all independent variables (ratio of interest expense, ratio of operational expenses, ratio of other income ratio, equity, and loans) that is used can affect competition conventional bank that proxy through revenue of commercial banks.

Recommendations which are suggested are any special arrangement regarding the restriction of the maximum percentage of ownership of market share, either in the form of assets, deposits and loans. Determination of the maximum percentage restriction must be accompanied by special regulations concerning the control of unfair competition practices in the national banking industry.

Economics and Finance in Indonesia Vol. 62 No. 1, April 2016, pp. 17-29 
Table 9: Appendix 1 Testing Results Chow

Redundant Fixed Effects Tests

Pool: REV

Test cross-section fixed effects

\begin{tabular}{llcc}
\hline Effects Test & Statistic & d.f. & Prob. \\
\hline Cross-section F & 13.563 .304 & $-8,93$ & 0.0000 \\
Cross-section Chi-square & 83.507 .955 & 8 & 0.0000 \\
\hline
\end{tabular}

Cross-section fixed effects test equation:

Dependent Variable: REV?

Method: Panel Least Squares

Date: 11/07/15 Time: 08:00

Sample: 20032014

Included observations: 12

Cross-sections included: 9

Total pool (balanced) observations: 108

\begin{tabular}{lclcc}
\hline \hline Variable & Coefficient & Std. Error & t-Statistic & Prob. \\
\hline C & 0.051552 & 0.013101 & 3.934 .829 & 0.0002 \\
INT? & 0.061593 & 0.019928 & 3.090 .791 & 0.0026 \\
OPS? & 1.273 .557 & 0.151023 & 8.432 .851 & 0.0000 \\
ROP? & -1.489 .685 & 0.241824 & -6.160 .200 & 0.0000 \\
EQ? & 0.067942 & 0.068214 & 0.996002 & 0.3216 \\
LO? & -0.035189 & 0.017022 & -2.067 .210 & 0.0413 \\
LF? & 0.025984 & 0.016421 & 1.582 .333 & 0.1167 \\
\hline R-squared & 0.647504 & Mean dependent var & & 0.099664 \\
Adjusted R-squared & 0.626563 & S.D. dependent var & & 0.022718 \\
S.E. of regression & 0.013883 & Akaike info criterion & -5.653 .723 \\
Sum squared resid & 0.019466 & Schwarz criterion & -5.479 .881 \\
Log likelihood & 3.123 .010 & Hannan-Quinn criter. & & -5.583 .236 \\
F-statistic & 3.092 .131 & Durbin-Watson stat & & 0.792328 \\
Prob(F-statistic) & 0.000000 & & & \\
\hline
\end{tabular}

\section{References}

[1] Andriawan, T 2012, 'Analisis Dampak Penerapan Kebijakan Arsitektur Perbankan Indonesia (API) terhadap Struktur Persaingan dan Stabilitas Bank Umum di Indonesia'. Tesis. Fakultas Ekonomi. Program Magister Perencanaan dan Kebijakan Publik. Kekhususan Ekonomi Keuangan dan Perbankan. Universitas Indonesia.

[2] Bank Indonesia 2010, Kajian Stabilitas Keuangan No.14 Maret 2010. Bank Indonesia. Departemen Penelitian dan Pengaturan Perbankan. Grup Stabilitas Sistem Keuangan.

[3] Berger, AN, Klapper, LF \& Turk, R 2008, 'Bank Competition and Financial Stability', World Bank Policy Research Working Paper, (4696).

[4] Bikker, JA, \& Groenevald, JM 2000, Competition and Concentration in the EU Banking Industry: Causes, Consequences, and Implications for the Future. De Nederlandsche Bank NV.

[5] Cetorelli, N 2001, 'Competition Among Banks: Good or Bad?', Economic Perspective Federal Reserve Bank of Chicago, vol. 25, no. 2, pp.38-48.

[6] Claessens, S, \& Laeven, L 2004, 'What Drives Bank Competition? Some International Evidence', Journal of Money, Credit and Banking, vol. 36, no. 3, Part 2: Bank Concentration and Competition: An Evolution in the Making A Conference Sponsored by the Federal Reserve Bank of Cleveland May 21-23, 2003, pp. 563-583.

[7] De Bandt, O, \& Davis, EP 2000, 'Competition, Contestability and Market Structure in European Banking Sectors on the Eve of EMU', Journal of Banking \& Finance, vol. 24, no. 6, pp.1045-1066.

[8] Demirgüç-Kunt, A, Laeven, L, \& Levine, R 2004, Regulations, Market Structure, Institutions, and the Cost of Financial Intermediation', Journal of Money, Credit and Banking, vol. 36, no. 3, pp. 593-622.

[9] de Rozas, L Guitiérrez 2007, 'Testing for Competition in the Spanish Banking Industry: The Panzar-Rosse Approach Revisited', Banco de España Research Paper No. WP0726.

[10] Fungáčová, Z, \& Weill, L 2009, 'How Market Power Influences Bank Failures: Evidence from Russia', BOFIT Institute for Economies in Transition Discussion Papers 12. Bank of Finland.

[11] Gajurel, DP, \& Pradhan, RS 2012, 'Concentration and Competition in Nepalese Banking', Journal of Business Economics Finance, vol. 1, no. 1, pp. 5-16.

[12] Mulyaningsih, T \& Daly, A 2011, 'Competitive Conditions in Banking Industry: An Empirical Analysis of the Consolidation, Competition and Concentration in the Indonesia Banking Industry between 2001 and 2009', Buletin Ekonomi Moneter dan Perbankan, vol. 14, no. 2, pp. 141-175.

[13] Mishkin, FS 2008, The Economic of Money, Banking, and Financial Markets, 8th Edition, Pearson Education, New Jersey.

[14] Nachrowi, DN \& Usman, H 2006, Pendekatan Populer dan Praktis Ekonometrika Untuk Analisis Ekonomi dan Keuangan, Lembaga Penerbit Fakultas Ekonomi Universitas Indonesia, Jakarta.

[15] Setyowati, R 2004, 'Tingkat Persaingan Industri Perbankan di Indonesia Tahun 1991-2002', Thesis, Fakultas Ekonomi Universitas Indonesia. 
Table 10: Appendix 2 Test Results Hausman

Correlated Random Effects - Hausman Test

Pool: REV

Test cross-section random effects

\begin{tabular}{|c|c|c|c|c|}
\hline Test Summary & & Chi-Sq. Statistic & Chi-Sq. d.f. & Prob. \\
\hline Cross-section random & & 37.443 .558 & 6 & 0.0000 \\
\hline \multicolumn{5}{|c|}{ Cross-section random effects test comparisons: } \\
\hline Variable & Fixed & Random & $\operatorname{Var}$ (Diff.) & Prob. \\
\hline INT? & 0.107440 & 0.088314 & 0.000077 & 0.0288 \\
\hline OPS? & 0.866810 & 1.050 .663 & 0.004423 & 0.0057 \\
\hline ROP? & -0.767165 & -1.137 .822 & 0.019724 & 0.0083 \\
\hline EQ? & -0.033694 & 0.017639 & 0.001457 & 0.1786 \\
\hline LO? & -0.059895 & -0.054305 & 0.000087 & 0.5481 \\
\hline LF? & 0.013404 & 0.027586 & 0.000134 & 0.2202 \\
\hline
\end{tabular}

Cross-section random effects test equation:

Dependent Variable: REV?

Method: Panel Least Squares

Date: 11/07/15 Time: 08:00

Sample: 20032014

Included observations: 12

Cross-sections included: 9

Total pool (balanced) observations: 108

\begin{tabular}{|c|c|c|c|c|}
\hline Variable & Coefficient & Std. Error & t-Statistic & Prob. \\
\hline C & 0.084209 & 0.013705 & 6.144 .531 & 0.0000 \\
\hline INT? & 0.107440 & 0.019113 & 5.621 .187 & 0.0000 \\
\hline OPS? & 0.866810 & 0.145353 & 5.963 .482 & 0.0000 \\
\hline ROP? & -0.767165 & 0.257589 & -2.978 .255 & 0.0037 \\
\hline EQ? & -0.033694 & 0.073165 & -0.460521 & 0.6462 \\
\hline LO? & -0.059895 & 0.018147 & -3.300 .493 & 0.0014 \\
\hline LF? & 0.013404 & 0.019785 & 0.677504 & 0.4998 \\
\hline \multicolumn{5}{|c|}{ Effects Specification } \\
\hline \multicolumn{5}{|c|}{ Cross-section fixed (dummy variables) } \\
\hline R-squared & 0.837315 & Mean dependent var & & 0.099664 \\
\hline Adjusted R-squared & 0.812824 & S.D. dependent var & & 0.022718 \\
\hline S.E. of regression & 0.009829 & Akaike info criterion & & -6.278 .796 \\
\hline Sum squared resid & 0.008984 & Schwarz criterion & & -5.906 .278 \\
\hline Log likelihood & 3.540 .550 & Hannan-Quinn criter. & & -6.127 .754 \\
\hline F-statistic & 3.418 .968 & Durbin-Watson stat & & 1.495 .712 \\
\hline Prob(F-statistic) & 0.000000 & & & \\
\hline
\end{tabular}


Table 11: Appendix 3 Results Panel Data Regression Model Estimation Fixed Effect

Dependent Variable: REV?

Method: Pooled Least Squares

Date: 11/07/15 Time: 07:58

Sample: 20032014

Included observations: 12

Cross-sections included: 9

Total pool (balanced) observations: 108

\begin{tabular}{lcccc}
\hline \hline Variable & Coefficient & Std. Error & t-Statistic & Prob. \\
\hline C & 0.084209 & 0.013705 & 6.144 .531 & 0.0000 \\
INT? & 0.107440 & 0.019113 & 5.621 .187 & 0.0000 \\
OPS? & 0.866810 & 0.145353 & 5.963 .482 & 0.0000 \\
ROP? & -0.767165 & 0.257589 & -2.978 .255 & 0.0037 \\
EQ? & -0.033694 & 0.073165 & -0.460521 & 0.6462 \\
LO? & -0.059895 & 0.018147 & -3.300 .493 & 0.0014 \\
LF? & 0.013404 & 0.019785 & 0.677504 & 0.4998 \\
Fixed Effects (Cross) & & & \\
A-C & -0.008249 & & \\
-B-C & 0.014121 & & \\
-C-C & -0.011617 & & \\
-D-C & -0.015979 & & \\
-E-C & 0.015187 & & \\
-F-C & 0.010649 & & & \\
-G-C & 0.013980 & & & \\
-H-C & & & \\
-C & 0.002800 & & & \\
\hline
\end{tabular}

Effects Specification

\begin{tabular}{lllc}
\hline \hline Cross-section fixed (dummy variables) & & & \\
R-squared & 0.837315 & Mean dependent var & 0.099664 \\
Adjusted R-squared & 0.812824 & S.D. dependent var & 0.022718 \\
S.E. of regression & 0.009829 & Akaike info criterion & -6.278 .796 \\
Sum squared resid & 0.008984 & Schwarz criterion & -5.906 .278 \\
Log likelihood & 3.540 .550 & Hannan-Quinn criter. & -6.127 .754 \\
F-statistic & 3.418 .968 & Durbin-Watson stat & 1.495 .712 \\
Prob(F-statistic) & 0.000000 & & \\
\hline \hline
\end{tabular}

Table 12: Appendix 4. Descriptive Statistics Competition Bank

\begin{tabular}{lccccccc}
\hline \hline & REV & INT & OPS & ROP & EQ & LO & LF \\
\hline Mean & 0.099664 & 0.161141 & 0.041023 & 0.014440 & 0.108472 & 0.544471 & 0.740522 \\
Median & 0.098055 & 0.138267 & 0.039619 & 0.013697 & 0.102671 & 0.572574 & 0.770200 \\
Maximum & 0.163740 & 0.555497 & 0.084938 & 0.039552 & 0.188481 & 0.767173 & 0.852184 \\
Minimum & 0.062508 & 0.046926 & 0.018147 & 0.004221 & 0.058940 & 0.220567 & 0.325655 \\
Std. Dev. & 0.022718 & 0.088971 & 0.011414 & 0.007022 & 0.026290 & 0.124401 & 0.094743 \\
Skewness & 0.575161 & 1.750 .696 & 0.864152 & 1.032 .753 & 0.856558 & -0.505705 & -2.018 .905 \\
Kurtosis & 2.933 .455 & 6.834 .688 & 4.163 .871 & 4.192 .627 & 3.800 .449 & 2.346 .223 & 7.870 .872 \\
& & & & & & & \\
Jarque-Bera & 5.974 .520 & 1.213 .406 & 1.953 .733 & 2.559 .901 & 1.608 .969 & 6.526 .692 & 1.801 .319 \\
Probability & 0.050425 & 0.000000 & 0.000057 & 0.000003 & 0.000321 & 0.038260 & 0.000000 \\
Sum & & & & & & & \\
Sum Sq. Dev. & 0.055223 & 0.846988 & 0.013939 & 0.005276 & 0.073956 & 1.655 .902 & 0.960465 \\
& & & & & & & \\
Observations & 108 & 108 & 108 & 108 & 108 & 108 & 108 \\
\hline \hline
\end{tabular}

Economics and Finance in Indonesia Vol. 62 No. 1, April 2016, pp. 17-29 
[16] Schaeck, K, Čihák, M \& Wolfe, S 2006, 'Are More Comoetitive Banking Systems More Stable?', IMF Working Paper, WP/06/143. Available from: <https : //www . imf . org/ external/pubs/ft/wp/2006/wp06143.pdf>. [23 February 2015].

[17] VanHoose, D 2010, The Industrial Organization of Banking: Bank Behavior, Market Structure, and Regulation, Germany: Springer- Verlag Berlin Heidelberg.

[18] Yildirim, HS \& Philippatos, GC 2006, 'Restructuring, Consolidation and Competition in Latin American Banking Markets', Journal of Banking \& Finance, vol. 31, no. 3, pp. 629-639. 